\title{
Türkiye'de Özel Öğrenme Güçlüğü Olan Bireylerin Tanılama Sürecinin Rehberlik Araştırma Merkezi Perspektifinden İncelenmesi ${ }^{1}$
}

\author{
DOI: $10.26466 /$ opus.948202
}

\author{
$*$ \\ Kürșat Öğülmüș* \\ * Dr. Öğr. Üyesi, Kırıkkale Üniversitesi, Eğitim Fakültesi, Kırıkkale/Türkiye \\ E-Posta: kursatogulmus@hotmail.com \\ ORCID: 0000-0001-7551-6894
}

\begin{abstract}
Öz
$B u$ araştırma, rehberlik araştırma merkezlerince (RAM) yürütülen eğitsel tanılama sürecinde özel öğrenme güçlüğ̈̈ (ÖÖG) olan çocuklarm yaşadıkları sorunları belirlemek amacı ile gerçekleştirilmiştir. Bu araştırma ile ÖÖG olan çocukların tanılanma sürecinde ortaya çıkan sorunları ortaya konulması ve buna yönelik çözüm önerileri getirilmesi hedeflenmektedir. Bu hedef doğrultusunda tanılama süreci araştırmacılar tarafindan farkına varma, tanılama ve yönlendirme olarak ele alınmıştır. Araştırma, nitel araştırma modellerinden olgubilim modeli ile desenlenmiş, veriler yar yapılandırılmış görü̧̧̈eler aracılı̆̆ıyla toplanmıştır. Çalı̧̧ma grubunu Ege bölgesinde bir ilde bulunan bir RAM'da görevli 8 özel eğitim öğretmeni oluşturmaktadır. Araştırma sonucunda ÖÖG olan çocukların fark etme, tanılama ve yönlendirme süreçlerinin her bir basamağında bir takım sorunlarla karşılaştığı ortaya konulmuştur. Araştırma bulguları ışığında bu sorunlar, fark etme sürecinde ÖÖG olan çocukların RAM'a hiçbir müdahalede bulunulmadan yönlendirildiği, yönlendirmeyi yapan öğretmenlerin bilgi düzeylerinin yetersiz olduğu, yönlendirmede çocukla birlikte gönderilen evrakların ÖÖG karakteristik özelliklerini yansıtmadı ̆̆g, öğretmenlerin formları yalnızca bir prosedürü yerine getirmek amacı ile doldurulduğu ve rehberlik servisinin çocuk hakkında herhangi bir değerlendirmede bulunmadığı olarak belirlenmiştir. Tanılama sürecinde yapılan uygulamalar yetersiz bulunurken bu süreçte görev alan özel eğitim öğretmenlerinin de kendilerini yetersiz bulduğu saptanmıştır. Son olarak yönlendirme sürecine ilişkin ÖÖG olan çocukların yönlendirilmesinde kaynaştırma uygulamasından başka seçeneğin bulunmadığı, destek eğitim sonucunda yapılan izlemelerin verimli olduğu ancak personel yetersizliği ve iş yükünün fazla olması nedeniyle izleme çalışmalarımın verimli yapılamadığı belirlenmiştir.
\end{abstract}

Anahtar Kelimeler: ̈zel öğrenme güçlüğü, Farkına varma, Tanılama, Yönlendirme, Özel Eğitim, Rehberlik araştırma merkezi

${ }^{1}$ Bu çalışma 30. Ulusal Özel Eğitim Kongresinde sözlü bildiri olarak sunulmuştur. 


\title{
Investigation of the Diagnosis Process of Individuals with Specific Learning Difficulties in Turkey from the Perspective of the Guidance Research Center
}

\begin{abstract}
This research was carried out with the aim of determining the problems experienced by children with specific learning difficulties (SLD) during the educational diagnosis process carried out by guidance research centers (GRC). With this research, it is aimed to reveal the problems that arise during the diagnosis of children with SLD and to offer solutions for this. In line with this goal, the diagnostic process was addressed by the researchers as recognition, diagnosis and guidance. The research was designed with the phenomenological model, one of the qualitative research models, and the data were collected through semi-structured interviews. The working group consists of 8 special education teachers working in a RAM in a province in the Aegean region. As a result of the research, it has been revealed that children with SLD face some problems at each step of their recognition, diagnosis and guidance processes. In the light of the research findings, these problems are that children with SLDs in the process of noticing are directed to GRC without any intervention, the knowledge level of the teachers is insufficient, the documents sent with the child do not reflect the characteristics of the SLD, the teachers' forms are filled out only for the purpose of performing a procedure and guidance. It was determined that the service did not make any evaluation about the child. While the applications made in the diagnostic process were found to be insufficient, it was found that the special education teachers who took part in this process found themselves inadequate. Finally, regarding the guidance process; It has been determined that there is no option other than mainstreaming in guiding the children with SLD, the monitoring made as a result of the support training is efficient, but the monitoring studies are not efficient due to the lack of personnel and the workload.
\end{abstract}

Keywords: Specific Learning Difficulties, Recognition, Diagnosis and Guidance, Guidance Research Centers. 


\section{Giriş}

Birçok farklı tanımı bulunmakla birlikte ÖÖG yazılı/sözlü dili kullanmada/anlamada, matematiksel işlemleme becerilerinde, hareketleri koordine etme ya da dikkatini yöneltme becerilerinde bir takım güçlüklere yol açan bir yetersizlik türüdür (Melekoğlu, 2016). Bu alandaki çalışmaların temeli ilk olarak 1800 yılların başında Franz Joseph Gall tarafından yapılan çalışmalara dayanmaktadır. Daha sonra 1963 yılında Samuel Alexander Kirk tarafından ilk olarak öğrenme güçlüğü terimi kullanılmıştır (Çakıroğlu, 2018). Uzmanlarca yapılan alandaki çalışmaların geçmişi günümüzden bir asır öncesine dayanmasına rağmen Türkiye'de ÖÖG son zamanlarda adından sıklıkla bahsedilen bir yetersizlik türüdür (Görgün ve Melekoğlu, 2019). Tanı sistemlerinin geliştiği ülkelerde ÖÖG farkındalığının oldukça yüksek olduğu görülmektedir. Örneğin Amerika Birleşik Devletleri'nde (ABD) özel gereksinimli tüm bireylerin içerisinde ÖÖG olarak tanılanmış bireyler \% 42'lik bir dilim oluşturmaktadır (Cortiella ve Horowitz, 2014). Bu dilim Türkiye'de ise yalnızca \%3'tür (Melekoğlu, 2016). ABD'de var olan durumun Türkiye'de de benzer olacağı varsayıldığında Türkiye'de bu orandaki farklılığın tanı sistemlerindeki farklılıktan ortaya çıktığı düşünülebilir. Türkiye' de eğitsel tanılama, tıbbi rapor doğrultusunda eğitsel değerlendirme yapılarak gerçekleştirilmektedir. Eğitsel tanılama, bireyin gereksinimlerini karşılamada doğru kararların alınmasını kolaylaştırmak ve eğitsel olarak yapabileceklerini ortaya koyarak özel gereksinimlerini belirlemek amacıyla yapılan değerlendirme modelidir (Avcıoğlu, 2014). Eğitsel tanılama bireyin eğitim hayatına dair doğru kararların alınması açısından oldukça önemlidir (Taylor, 2014). Bu sebeple bireydeki farkl1lıklar ne kadar erken fark edilirse bir başka deyişle eğitsel tanılama ne kadar erken yapılırsa bireyin eğitim planlamasına olan olumlu yansımaları da o derece yüksek olacaktır (Lange ve Thompson, 2006). ÖÖG olan çocukların öğrenme güçlükleri çoğunlukla ilkokul döneminde fark edilmektedir. Bunun en belirgin nedeni yetersizlik alanlarının yalnızca akademik alanlarda ortaya çıkması olduğu söylenebilir (Korkmazlar, 1992). Bu nedenle ÖÖG olan çocuklar ilk olarak çoğunlukla örgün eğitime devam ettikleri sınıf öğretmenleri tarafından fark edilmektedir. Tanılama süreci bu 
sayede başlamaktadır. Türkiye'de ÖÖG dahil tüm özel gereksinimli bireylerin eğitsel tanılanması, uygun eğitim programına yönlendirilmesi ve bu öğrencilere yönelik uygun izleme çalışmalarının yapılması görevi Milli Eğitim Bakanlığı'na (MEB) bağlı kuruluşlar olan Rehberlik araştırma merkezlerine verilmiştir (Milli Eğitim Bakanlığı [MEB], 2018). Şekil 1'de ÖÖG tanılama süreci yer almaktadır.

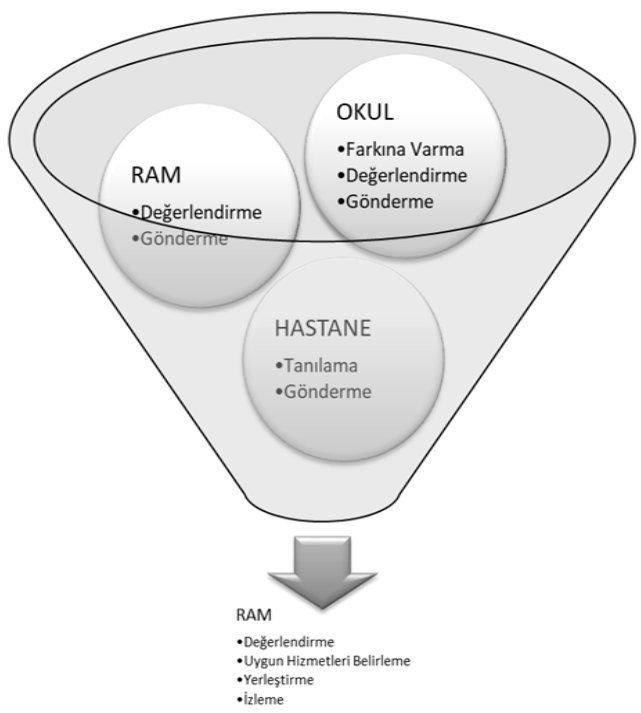

Şekil 1. ÖÖG tanılama süreci

RAM, eğitsel değerlendirme ve tanılama işlemlerini, RAM müdürü teklifi ve il/ilçe milli eğitim müdürlügünün onayı ile kurulan özel eğitim değerlendirme kurulu aracılığıyla yapmaktadır. Özel eğitim hizmetleri yönetmeliğine göre özel eğitim değerlendirme kurulu, rehberlik araştırma merkezi müdür yardımcısı başkanlığında (a) özel eğitim hizmetleri bölüm başkanı (b) en az bir psikolojik danışman ve (c) en az bir özel eğitim öğretmeninden oluşur. Kurula ayrıca ilgili bireyin velisi ya da kendisi de katılır. Buna ek olarak kurula görüşüne başvurulmak üzere ilgili kurum ve kuruluşların personeli de katılabilmektedir. İlkokul çağında sınıf öğretmeni ya da ailesi tarafından fark edilen birey ÖÖG şüphesiyle yaşadığ 1 bölgenin bağlı olduğu RAM'a başvurur. Daha sonra öğrencinin eğitsel 
performansı ve zeka bölümü puanının ölçülmesi amacıyla formal ve informal değerlendirme araçlarıyla değerlendirmeler yapılır. Bu süreçte kurum bünyesinde çalışan özel eğitim öğretmenleri ve psikolojik danışmanlar aktif görev almaktadır. Değerlendirme sonucunda uzmanlar tarafından uygun görüldüğü takdirde öğrenci hastaneye sevk edilir. Hastane değerlendirmesinde hekimler tarafından tıbbi olarak ÖÖG olduğu belirlenen birey, hastaneden düzenlenen raporunu rehberlik araştırma merkezine sunarak sürecin tamamlanmasını talep eder. Özel eğitim değerlendirme kurulu yapılan eğitsel değerlendirmeler ve hastane raporu doğrultusunda öğrenci için özel eğitim değerlendirme kurulu raporu düzenleyerek ÖÖG tanılama sürecini tamamlamış olur. Tanılamanın ardında kurul aynı zamanda öğrenciyi ilgi, istek ve gereksinimlerine uygun olarak eğitim programlarına yönlendirmektedir. Daha sonraki süreçte yönlendirilen eğitim programı süresi dolduğunda izleme çalışmaları gerçekleştirilmektedir. ÖÖG olan çocuklar, bu süreci adım adım takip etmekte ve nihai olarak RAM tarafından uygun eğitim programlarına yönlendirilmektedir.

Türkiye'de tanı almış ÖÖG olan çocukların diğer gereksinim grupları içerisindeki oranı göz önüne alınarak bu durum tanı sistemi gelişmiş diğer ülkelerle karşılaştırıldığında, Türkiye' de tanı alan çocukların sayısının az olmasının tanı sistemindeki bir takım güçlüklerden kaynaklandığı düşünülmektedir. Türkiye'de uygulanan mevcut tanı sistemindeki aksaklıkları ortaya koyan bir çok çalışma yapılmıştır. Avcıoğlu (2012) yaptığı bir çalışmada tarama programlarının yetersiz olduğunu, Yurtsever (2013) okullarda gerçekleştirilen gönderme öncesi süreçlerin yetersiz olduğunu, Tiryakioğlu ve Avcıŏ̆lu (2013) RAM ve sağlık kurumları arasında işbirliği problemlerinin yaşandığını, Yanık (2016) RAM'lar da kullanılan değerlendirme araçlarının yetersiz olduğunu belirterek tanı sistemindeki bazı aksaklıklar vurgulanmıştır. Yapılan çalışmalarda vurgulanan aksaklıklar genel olarak tanı sistemini ele alan çalışmalardan elde edilen bulgulara dayanmaktadır. Fakat tanı sistemindeki aksaklıkların ÖÖG özelinde ortaya koyulduğu çalışmalar incelendiğinde bu konuda yapılan çalışmaların oldukça sınırlı olduğu görülmüştür (Aksoy ve Şafak, 2021). Bu sınırlılık araştırmanın çıkış noktasını oluşturmuştur. $\mathrm{Bu}$ nedenle bu araştırmanın amacı, rehberlik araştırma merkezleri tarafından yürütülen eğitsel değerlendirme ve 
tanılama sürecindeki durumu ÖÖG özelinde ortaya koymaktır. Eğitsel değerlendirme ve tanılama süreci bu amaca uygun olarak araştırmacılar tarafından 1) farkına varma, 2) tanılama ve 3) yönlendirme olarak ele alınmıştır. Ele alınan bu süreç rehberlik araştırma merkezi eğitsel değerlendirme ve tanılama hizmetinde aktif olarak görev alan öğretmenlerin görüşleri alınarak incelenmiştir.

\section{Yöntem}

Etik Komite Onayı : Bu çalışma için etik komite uygunluk onayı Kırıkkale Üniversitesi Sosyal ve Beşeri Bilimler Araştırmaları etik kurulu 18.05.2021 tarih 5 nolu karar ile alınmıştır.

Araştırma Modeli: $\mathrm{Bu}$ araştırmada nitel araştırma modellerinden olgubilim (fenomenoloji) deseni kullanılmıştır. Olgu bilim deseninde yaşanmış olan deneyimlerin değerlendirmesi yapılmaktadır (Miller, 2003). Ayrıca olgubilim çalışmaları farkında olunan ancak ayrıntılı ve derinlemesine bir anlayışa sahip olunmayan olgulara odaklanan çalışmalardır (Cropley, 2002). Bu tür çalışmalarda veriler, üzerinde çalışılan olguyu yaşayan ve yansıtan birey ya da gruplarla görüşmeler yapılarak elde edilmektedir (Büyüköztürk vd., 2018).

Çalışma Grubu: Araştırmaya dahil olan katılımcılar, gönüllülük esasına dayanılarak amaçsal örnekleme yöntemlerinden ölçüt örnekleme tekniği kullanılarak belirlenmiştir. Ölçüt örnekleme, örneklemin problemle ilgili olarak belirlenen niteliklere sahip kişiler, olaylar, nesneler ya da durumlardan oluşturulmasıdır (Büyüköztürk vd., 2018). Örneklem ölçütleri ise; a) Özel eğitim öğretmeni olmak, b) Rehberlik araştırma merkezinde aktif olarak çalışıyor olmak ve c) ÖÖG tanılama biriminde görev yapıyor olmak olarak uygulanmıştır. Bu kapsamda araştırmaya Ege bölgesinde bir ilde bulunan rehberlik araştırma merkezinde görev yapan 8 öğretmen dahil edilmiştir. Araştırmaya dahil edilen katılımcı öğretmenlerin demografik bilgileri tabloda sunulmuştur (Bkz. Tablo 1). 
Tablo 1. Araştırma Grubunu Oluşturan Öğretmenlere Ait Demografik Bilgiler

\begin{tabular}{|c|c|c|c|c|c|c|c|}
\hline Yaş & Cinsiyet & Mezuniyet & Branş & $\begin{array}{l}\text { Den- } \\
\text { eyim } \\
\text { (Yil) }\end{array}$ & $\begin{array}{l}\text { RAM } \\
\text { Görev } \\
\text { Süresi } \\
(\text { Yil) }\end{array}$ & $\begin{array}{l}\text { RAM } \\
\text { Görev }\end{array}$ & $\begin{array}{l}\text { ÖÖG ile ilgili } \\
\text { eğitime } \\
\text { katılma du- } \\
\text { rumu }\end{array}$ \\
\hline 49 & E & Sınıf Öğrt. & Özel Eğitim & 28 & “6 & $\begin{array}{l}\text { Özel Eğt. } \\
\text { Böl. Bşk. }\end{array}$ & + \\
\hline 40 & K & Sınıf Öğrt. & Özel Eğitim & 16 & 6 & $\begin{array}{l}\text { Özel Eğitim } \\
\text { Öğretmeni }\end{array}$ & - \\
\hline 32 & E & $\begin{array}{l}\text { Zihin Engelliler } \\
\text { Sinıf Öğretmeni }\end{array}$ & Özel Eğitim & 5 & 1,5 & $\begin{array}{l}\text { Özel Eğitim } \\
\text { Öğretmeni }\end{array}$ & - \\
\hline 27 & K & $\begin{array}{l}\text { Zihin Engelliler } \\
\text { Sinıf Öğretmeni }\end{array}$ & Özel Eğitim & 4 & 1,5 & $\begin{array}{l}\text { Özel Eğitim } \\
\text { Öğretmeni }\end{array}$ & - \\
\hline 25 & K & $\begin{array}{l}\text { Görme Engelli- } \\
\text { ler Sinıf Öğret- } \\
\text { meni }\end{array}$ & Özel Eğitim & 3 & 1,5 & $\begin{array}{l}\text { Özel Ĕ̆itim } \\
\text { Öğretmeni }\end{array}$ & - \\
\hline 24 & E & $\begin{array}{l}\text { Zihin Engelliler } \\
\text { Sinıf Öğretmeni }\end{array}$ & Özel Eğitim & 2 & 1,5 & $\begin{array}{l}\text { Özel Eğitim } \\
\text { Öğretmeni }\end{array}$ & + \\
\hline 24 & K & $\begin{array}{l}\text { Zihin Engelliler } \\
\text { Sınıf Öğretmeni }\end{array}$ & Özel Eğitim & 2 & 1,5 & $\begin{array}{l}\text { Özel Eğitim } \\
\text { Öğretmeni }\end{array}$ & - \\
\hline 24 & K & $\begin{array}{l}\text { Zihin Engelliler } \\
\text { Sinıf Ögretmeni }\end{array}$ & Özel Eğitim & 1,5 & 1,5 & $\begin{array}{l}\text { Özel Eğitim } \\
\text { Öğretmeni }\end{array}$ & - \\
\hline
\end{tabular}

Verilerin Toplanması: Araştırma verileri yarı yapılandırılmış görüşme tekniği kullanılarak toplanmıştır. Görüşme, araştırma katılımcılarının duygu ve düşüncelerini anlatma etkinliği olarak tanımlanmaktadır (Karataş, 2015). Bir görüşme türü olan yarı yapılandırılmış görüşmeler; sahip olduğu belli düzeydeki standartlı̆̆ ve esnekliği, yazmaya ve doldurmaya dayalı testler ve anketlerdeki sinırlılığı ortadan kaldırması ve belirli bir konuda derinlemesine bilgi edinmeye yardımcı olması (Yıldırım ve Şimşek, 2003) nedeniyle araştırmacılar tarafından en çok tercih edilen görüşme tekniğidir (Karasar, 2002; Mason, 1996). Görüşmelerde kullanılan yarı yapılandırılmış görüşme formu soruları literatürdeki kaynaklar taranarak ve sahadaki tecrübelerden faydalanılarak hazırlanmıştır. Form için hazırlanan sorular, görünüş ve kapsam geçerliliği sağlanmak üzere ilgili alandaki uzmanlara gönderilerek uzman görüşlerine başvurulmuştur. Daha sonra görüşme formu, uzmanlardan gelen dönütler ışığında son halini almıştır. Yarı yapılandırılmış görüşme formu iki bölümden oluşmaktadır. İlk bölümde katılımcıların tanımlayıcı özelliklerini ortaya koyan ifadeler yer almaktadır (yaş, cinsiyet, mesleki tecrübe, öğrenim düzeyi vb.). İkinci bölümde ise ÖÖG olan öğrencilerin tanılanması sürecinde ortaya çıkan durumu belirlemeye yönelik soruların 
bulunduğu ifadeler yer almaktadır. Oluşturulan form yardımıla araştırmanın verileri katılımcıların kendi belirledikleri ortam ve zamanda toplanmıştır. Görüşme soruları her bir katılımcıya, aynı uygulamacı tarafından yöneltilmiş olup yapılan görüşmeler ses kayıt cihazı ile kayıt altına alınarak daha sonra çözümlenmiştir. Verilerin güvenirliğini sağlamak için kayıtlar diğer araştırmacı tarafından incelenerek kontrol edilmiştir.

Verilerin Analizi: Araştırma kapsamında elde edilen veriler nitel araştırma modelinin doğası doğrultusunda dikkatli bir şekilde okunarak kategoriler oluşturulmuş ve içerik analizleri yapılmıştır. Içerik analizi belirli kurallara dayalı kodlamalarla, bir metnin bazı sözcüklerinin daha küçük tema kategorileri ile özetlendiği sistematik ve yinelenebilir bir teknik olarak tanımlanmaktadır (Büyüköztürk vd., 2018). İçerik analizinde güvenirliğin belirlenmesi amacıyla uyuşum yüzdesi formülü kullanılmıştır. Uyuşum yüzdesi (Agreement percentage) "Güvenirlik = Görüş birliği / (Görüş Birliğgi + Görüş Ayrılığı) x 100" formülü kullanılarak hesaplanmıştır (Miles ve Huberman, 1994). Çalışmada, bu formül kullanılarak kodlamalardaki uyuşum yüzdesinin 0.91 olduğu belirlenmiştir.

\section{Bulgular}

Bu bölümde görüşmeler sonucunda öğretmenlerden elde edilen verilerle oluşturulan temalara ve alt temalara yer verilmiştir Görüşmelerde rehberlik araştırma merkezi özel eğitim bölümü tanılama biriminde görev alan öğretmenlerin verdiği yanıtlar (a) farkına varma), (b) tanılama ve (c) yönlendirme olmak üzere üç bölümde ele alınmıştır.

\section{Farkına varma}

Rehberlik araştırma merkezine ÖÖG şüphesiyle yönlendirilen öğrencilerle ilgili gönderme öncesinde öğretmenleri tarafından yapılan müdahalelerde beş farklı madde kodlanmıştır. Bu kategoride en fazla kodlanan madde (f:4) herhangi bir müdahale yapılmadan (akademik olarak başarısız olan öğrenciler sınıf öğretmenlerinin gözlemlerine dayalı olarak) 
gönderilmesi iken daha sonra sirasıyla, öğrencinin durumu değerlendirilerek özel bir müdahale planı hazırlanarak uygulanıyor (f:2), aynı program uygulanıyor sadece birebir ilgileniliyor (f:1), harf farkındalığı kazandırmaya yönelik çalışmalar yapılıyor (f:1), genel önlemler (yer değiştirme, ön sırada oturtma, rehberlik servisi ile görüşme, veli ile görüşme vb.) alınıyor (f:1) maddeleri takip etmektedir.

Tablo 2. Rehberlik araştırma merkezine ÖÖG şüphesiyle yönlendirilen öğrencilerle ilgili gönderme öncesinde öğretmenleri tarafından yapılan müdahalelere yönelik kodlanan maddeler

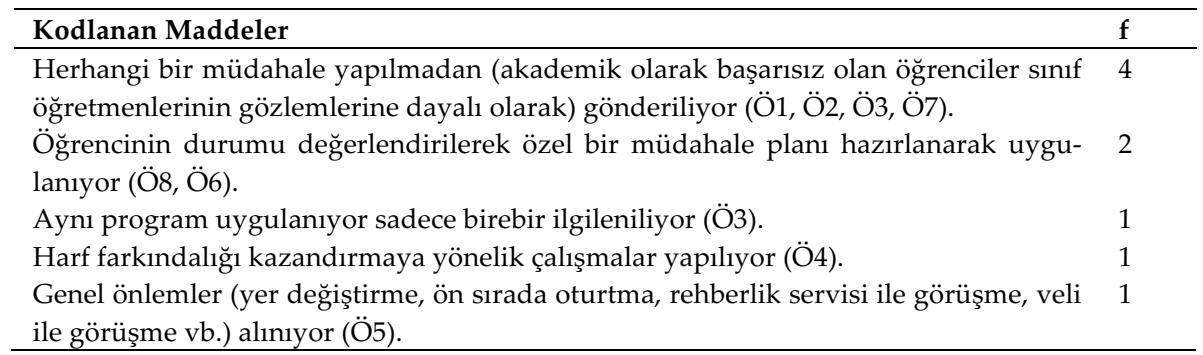

Öğretmenlerin kendi ifadelerinden bazı kesitler aşağıda yer almaktadir;

"Genellikle sını öğretmeni dışında öğrenci ile ilgili herhangi bir çalışma yapılmıyor. Sadece sını öğretmeninin gözlem ve çabalar sonrasında öğrenci rehberlik ve araştırma merkezine yönlendiriliyor"(Ö1).

"Bence akademik olarak derslerinde başarısız olan çocuklar rehberlik araştırma merkezine yönlendiriliyor"(Ö2).

“Öğrenci ile birlikte gönderilen raporlarda çoğunlukla öğretmenlerin her hangi bir müdahalede bulunmadığı görülmektedir. Müdahalede bulunanların ise öğrencilerle özel çalışmalar yapmadıkları diğer normal gelişim gösteren akranlarına yönelik yaptıkları çalışmalarla aynı olduğu görülmüş̧ür. Tek fark ÖÖG olan öğrencilerle bire bir ilgilenmeleridir"(Ö3).

"Genelde bu öğrencilerde harf farkındalığını kazandırmaya yönelik çalışmalar yapıyor öğretmenler. Örneğin b ile d harflerini karıştıran öğrenciler için b'nin altına nokta koymak gibi."(Ö4).

Rehberlik araştırma merkezinde görevli özel eğitim öğretmenlerinin tamamı (f:8), müdahalede bulunan öğretmenlerin, gönderme öncesinde 
ÖÖG olan öğrencilere yapılması gereken müdahaleler konusundaki bilgi düzeylerinin yetersiz olduğunu ifade etmişlerdir.

Tablo 3. Öğretmenlerin, öğrenciyi rehberlik araşttrma merkezine yönlendirmeden önce gönderme öncesi süreçte yapılması gereken müdahaleler konusundaki bilgi düzeylerine yönelik kodlanan maddeler

\begin{tabular}{lc}
\hline Kodlanan Maddeler & f \\
\hline Müdahalede bulunan öğretmenlerin ÖÖG olan öğrencilere yapilan müdahaleler ko- & 8 \\
nusundaki bilgi düzeylerinin oldukça yetersiz olduğunu düşünüyorum (Ö1, Ö2, Ö3, \\
Ö4, Ö5, Ö6, Ö7, Ö8).
\end{tabular}

Öğretmenlerin kendi ifadelerinden bazı kesitler aşağıda yer almaktadır;

"Mevzuat noktasinda gerek öğretmen gerek okul idaresi çok yetersiz ve bu konu üzerinde araştırma yapma gereği duymuyor. Hele ailenin sosyo-ekonomik düzeyi düşükse bütün sebepler buna dayandırılarak herhangi bir müdahale gereği duyulmuyor sadece bilinçli ailelerde çoğunlukla ailenin talebi üzerine rehberlik araştırma merkezine gelmeden önce gerekli müdahaleler yapılmaya çalışılıyor. Ancak bu müdahalelerle ilgili sını öğretmeninin yapması gerekenleri bilmediğine şahit oluyoruz."(Ö1).

"Müdahalede bulunan çok az öğretmenin yaptığı çalışmalara bakılarak şu söylenebilir ki özel öğrenme güçlüğü olan öğrencilere yönelik yapılan müdahaleler normal gelişim gösteren akranlarına yapılan müdahaleler ile aynıdır. ÖÖG olan öğrencilere yönelik her hangi bir farklılaştırma yapılmamaktadır. Yapılan tek farklılaştırma öğretimin bireyselleştirilmesidir. Bu durumdan yola çıkarak müdahalede bulunan öğretmenlerin ÖÖG olan öğrencilere yapılan müdahaleler konusundaki bilgi düzeylerinin oldukça yetersiz olduğunu göstermektedir."(Ö3).

Tablo 4. Rehberlik araştırma merkezine ÖÖG şüphesiyle yönlendirilen öğrencilerin öğretmenleri tarafindan uygulanan değerlendirme formunun niteliğine ilişkin görüşlere ilişkin kodlanan maddeler

\begin{tabular}{lc}
\hline Kodlanan Maddeler & f \\
\hline Gereksinim durumu gözetilmeksizin prosedürü yerine getirmek için genel bilgilerle & 5 \\
özensiz bir şekilde doldurulduğunu düşünüyorum (Ö7, Ö2, Ö1, Ö3, Ö5). \\
$\begin{array}{l}\text { Değerlendirme süreci zaman alıcı ve zorlayıcı bir süreç olduğundan objektif } \\
\text { yapıldığını düşünmüyorum (Ö8). }\end{array}$ \\
$\begin{array}{l}\text { Formların işlevsel olduğunu düşünüyorum (Ö4). } \\
\text { Formların yetersiz olduğunu düşünüyorum (Ö6). }\end{array}$ \\
\hline
\end{tabular}


ÖÖG şüphesi bulunan öğrenci rehberlik araştırma merkezine yönlendirilirken öğrenci için doldurulan formların niteliği ile ilgili dört farklı madde kodlanmıştır. Bu kategoride en çok kodlanan madde (f:5) Gereksinim durumu gözetilmeksizin prosedürü yerine getirmek için genel bilgilerle özensiz bir şekilde doldurulduğunu düşünüyorum iken daha sonra sırasıyla, değerlendirme süreci zaman alıcı ve zorlayıcı bir süreç olduğundan objektif yapıldığını düşünmüyorum (f:1), formların işlevsel olduğunu düşünüyorum (f:1), formların yetersiz olduğunu düşünüyorum (f:1) maddeleri takip etmektedir.

Öğretmenlerin kendi ifadelerinden bazı kesitler aşağıda yer almaktadır;

"Aslında öğretmenler çocukla ilgili tespitlerini olduğu gibi yazmaktan veli tepkisi yüzünden çekiniyorlar. Bazı öğretmenlerimiz de baştan savma doldurduklarn için eğitsel değerlendirme formu, bilişsel değerlendirme formu rehberlik araştırma merkezinde bize çok ışık tutmuyor"(Ö1).

"ilk olarak öğretmen eğitsel değerlendirme formundaki soruları basit olarak cevaplıyor. Bunun yanında eğitsel değerlendirme formundaki açık uçlu sorulara açıklayıcı cevaplar yazmak yerine çoğu öğretmen evet var, hayır yok gibi kısa cevaplar yazmayı tercih ediyor. Ya da çoğunluğunda olduğu gibi öğrencinin birçok alanda sinıfin gerisinde olduğunu belirtiyor. Bu bakımdan bu formlardan pek verim aldığımız söylenemez. Hatta özenle doldurulmuş bir form gördüğ̈̈müzde şaşırıp öğretmen arkadaşlarla birbirimize gösteriyoruz"(Ö7).

ÖÖG şüphesiyle yönlendirilen öğrenciler için düzenlenen ve öğrencinin beraberinde gönderilen formların ÖÖG karakteristik özelliklerini destekleme düzeyine ilişkin üç farklı madde kodlanmıştır. Bu Kategoride en fazla kodlanan madde (f:5) ÖÖG karakteristik özelliklerini desteklemiyor iken daha sonra sırasıyla, ÖÖG karakteristik özelliklerini kısmen desteklemektedir (f:2), ÖÖG karakteristik özelliklerini desteklemektedir (f:1) maddeleri takip etmektedir.

Tablo 5. Rehberlik araştırma merkezine ÖÖG şüphesiyle yönlendirilen öğrencilerin ögretmenleri tarafindan düzenlenen formlarn ÖÖG karakteristik özelliklerini destekleme dïzeyine ilişkin kodlanan maddeler

\begin{tabular}{lc}
\hline Kodlanan Maddeler & f \\
\hline ÖÖG karakteristik özelliklerini desteklemiyor (Ö4, Ö5, Ö8, Ö1, Ö2). & 5 \\
ÖÖG karakteristik özelliklerini k1smen desteklemektedir (Ö3, Ö4). & 2 \\
ÖÖG karakteristik özelliklerini desteklemektedir (Ö7). & 1 \\
\hline
\end{tabular}


Öğretmenlerin kendi ifadelerinden bazı kesitler aşağıda yer almaktadır;

“Düzenlenen formlarda yer verilen bilgiler ÖÖG karakteristik özelliklerini gösteriyor ancak formları amaca uygun dolduran öğretmenler bile ÖÖG değil çoğunlukla zihinsel yetersizlik düşüncesi içinde oluyorlar"(Ö1).

“Okullarda görev yapan öğretmenlerin özel öğrenme güçlüğ̈̈ ile alakalı gereken donanıma sahip olduğunu varsayarak hazırlanmış. Okullarda görev yapan sinıf ve branş öğretmenleri ÖÖG hakkında gerekli birikime sahip olmadiğ için okullar tarafindan düzenlenen formlar özel öğrenme güçlüğ̈̈nü karakteristik özeliklerini kısmen destekler nitelikte oluyor. İlgili yetersizlik alanında öğretmenler tarafindan en bilinen karakteristik özellik harfleri ve sayıları ters yazma olduğu için formlar bu durumu ifade edecek şekilde düzenlenebiliyor"(Ö5).

“Öğrencilerin genel olarak akademik derslerde sinıfin gerisinde ya da sosyal alanlara katılımın beklenilen düzeyde olmadığını belirtiyorlar. Ya da öğrenci de harf ve rakamlarn ters yazma gibi bir durum varsa bunu yazabiliyorlar. Bu bakımdan destekler nitelikte olduğunu söyleyebilirim"(Ö7).

Tablo 6. Rehberlik araştırma merkezine ÖÖG şüphesiyle yönlendirilen öğrenci için devam ettiği okul rehberlik servisi tarafindan yapılan değerlendirmelere ilişkin kodlanan maddeler

\begin{tabular}{lc}
\hline Kodlanan Maddeler & $\mathbf{f}$ \\
\hline Herhangi bir değerlendirme yapılmamaktadır (Ö1,Ö2,Ö3,Ö6,Ö7). & 5 \\
Gönderme öncesi süreçte neler yapıldığına yönelik açıklamalar yapılmaktadır (Ö4, Ö5). & 2 \\
Akademik ve sosyal becerilere yönelik değerlendirmeler yapılmaktadır (Ö8). & 1 \\
\hline
\end{tabular}

Rehberlik araştırma merkezine ÖÖG şüphesi ile yönlendirilen öğrenciler için rehberlik servisi tarafından yapılan değerlendirmelerde üç farklı madde kodlanmıştır. Bu kategoride en fazla kodlanan madde (f:5) herhangi bir değerlendirme yapılmaması iken daha sonra sırasıyla, gönderme öncesi süreçte neler yapıldığına yönelik açıklamalar yapılmaktadır (f:2), akademik ve sosyal becerilere yönelik değerlendirmeler yapılmaktadır (f:1) maddeleri takip etmektedir.

Öğretmenlerin kendi ifadelerinden bazı kesitler aşağıda yer almaktadır;

“Okul rehberlik servisi bu konuda çok fazla devreye girmiyor. Çoğunlukla sinuf rehber öğretmeninin değerlendirmelerine paralel görüş bildiriliyor. Rehberlik araştırma merkezinde öğrencilerle ilgili değerlendirmelerde kesin kanaate 
varamadı̆̆ımız durumlarda rehberlik servisi ile görüşme ihtiyacı hissettiğimizde rehberlik servisi bu durumda devreye giriyor. Düzenlenen formlarda öğrencinin ailesiyle ilgili çok fazla bilgilere ulaşamıyoruz"(Ö1).

"Formlardaki verimsizlik bu kısmada yansımıştır. Formun en arka kısmındaki rehber öğretmeni görüşlerine bakılarak sinırlı düzeyde bilgi ve değerlendirmelere ulaşılabilmektedir. Çok az rehber öğretmeni ayrıca bu konuda rapor göndermektedir. Gönderilen raporlarda da genellikle öğrencinin akademik motivasyonu ve davranış problemleri ile ilgili bilgi ve değerlendirmelere yer verildiği görülmektedir"(Ö3).

"Okul rehberlik servisinden gelen görüş yazısında genellikle öğretmenlerin görüş yazısı gibi tek kelimelik cevaplar mevcut olabiliyor. Bazı rehber öğretmenlerimiz disleksiden şüphelendiklerini belirtiyor. Bazıları da sadece imzasını atıp gönderiyor"(Ö7).

Tablo 7. Rehberlik araştırma merkezine ÖÖG şüphesiyle yönlendirilen çocukların yaş gruplarna ilişkin kodlanan maddeler

\begin{tabular}{ll}
\hline Kodlanan Maddeler & f \\
\hline $7-12$ yaş arası (Ö6, Ö7, Ö3, Ö8, Ö4) & 5 \\
6-10 yaş aras1 (Ö1, Ö2, Ö5) & 3 \\
\hline
\end{tabular}

Rehberlik araştırma merkezine ÖÖG şüphesiyle yönlendirilen çocukların yaş gruplarına yönelik iki farklı madde kodlanmıştır. Bu kategoride en fazla kodlanan madde (f:5) 7-12 yaş arası iken diğer kodlanan madde ise 6-12 yaş arası maddesidir.

\section{Tanılama}

Tablo 8. Rehberlik araştırma merkezi tanılama sürecinin (inceleme ve hastaneye yönlendirme vs.) verimliliğine ilişkin kodlanan maddeler

\begin{tabular}{ll}
\hline Kodlanan Maddeler & f \\
\hline $\begin{array}{l}\text { Rehberlik araştırma merkezinde yürütülen eğitsel tanılama sürecini verimsiz buluy- } \\
\text { orum (Ö3, Ö8, Ö4, Ö5). }\end{array}$ & 4 \\
$\begin{array}{l}\text { Rehberlik araştırma merkezinde yürütülen eğitsel tanılama sürecini verimli (performans } \\
\text { değerlendirme ve zeka testi doğru sonuca götürüyor) buluyorum (Ö2, Ö7). }\end{array}$ & 2 \\
$\begin{array}{l}\text { Rehberlik araştırma merkezinde yapılan eğitsel tanılama ve değerlendirmeler hastanede } \\
\text { tıbbi tanılamaya yönelik yapılan eğitsel tanılama ve değerlendirmelerden daha niteli- }\end{array}$ & 1 \\
$\begin{array}{l}\text { klidir (Ö1). } \\
\begin{array}{l}\text { Rehberlik araştırma merkezi tanılama sürecinden (inceleme, hastaneye yönlendirme vs.) } \\
\text { net sonuçlar elde edilemediği için belirsizliğe sebep olduğunu düşünüyorum (Ö6). }\end{array}\end{array}$ \\
\hline
\end{tabular}


Rehberlik araştırma merkezi tanılama sürecinin verimliliğine yönelik soru ile ilgili dört farklı madde kodlanmıştır. Bu kategoride en fazla kodlanan madde (f:4) rehberlik araştırma merkezinde yürütülen eğitsel tanılama sürecini verimsiz buluyorum maddesi iken daha sonra sırasıyla, rehberlik araştırma merkezinde yürütülen eğitsel tanılama sürecini verimli (performans değerlendirme ve zeka testi doğru sonuca götürüyor) buluyorum (f:2), rehberlik araştırma merkezinde yapılan eğitsel tanılama ve değerlendirmeler hastanede tıbbi tanılamaya yönelik yapılan eğitsel tanılama ve değerlendirmelerden daha niteliklidir (f:1), rehberlik araştırma merkezi tanılama sürecinden (inceleme, hastaneye yönlendirme vs.) net sonuçlar elde edilemediği için belirsizliğe sebep olduğunu düşünüyorum (f:1) maddeleri takip etmektedir.

Öğretmenlerin kendi ifadelerinden bazı kesitler aşağıda yer almaktadır;

“Öncelikle bu konuda ilk üzerinde durulması gereken nokta ÖÖG tanısının rehberlik araştırma merkezi tarafindan tek başına konulamamasıdır. Çünkü yönlendirilen öğrenciler çoğunlukla hiçbir müdahale yapılmaksızın gönderilmekte olup bir kaba değerlendirme formu ve yapılacak olan zeka testi ile değerlendirilmektedir. Bu işlemler yapıldıktan sonra eğer testleri yapan uzmanlar ÖÖG'den şüphelenirse ancak öğrenciyi hastaneye yönlendirerek hastaneden alınacak olan sağlık kurulu raporu ile ÖÖG tanısını koyulabilmektedir. Burada eleştirilecek olan nokta şüphesiz hastanede yapılan değerlendirmeninde hekimler tarafindan zeka testi ile yapılması nedeniyle ayn işlemin eğitimciler tarafindan rehberlik araştırma merkezinde yapılmasına rağmen rehberlik araştırma merkezinin tek başına bu tanıyı koyamamasıdır. Tüm noktalara bakıldı̆̆ında rehberlik araştırma merkezindeki tanılama sürecinin ÖÖG'yi tanılamada oldukça verimsiz olduğu söylenebilir"(Ö3).

"Bize yönlendirilen ve daha önce hastane raporu almamış öğrencileri biz ilk olarak zihin yetersizliği modülüyle inceliyoruz. Zihin yetersizliği modülündeki Türkçe ve matematik bölümü özel öğrenme güçlü̆̈̈̈ olan çocukları fark etmemizde daha çok işe yarıyor. Illk incelemenin ardından öğrencide özel öğrenme güçlüğü olduğu şüphesini duyarsak öğrenciyi zeka testine alıyoruz. Sonrasinda ise sonuca hastaneye yönlendirme sürecini başlatıyoruz. Bu sürecin öğrencinin tanılanmasında verimli geçtiğini düşünüyorum. Çünkü tanıyı koyana kadar öğrenci sını öğretmeni, rehberlik araştırma merkezin ve hastane tarafindan üç aşamalı olarak incelenmiş oluyor"(Ö7). 
Tablo 9. Rehberlik araştırma merkezinde ÖÖG olan çocuklan tanılamada ne tür ölçme ve değerlendirme teknikleri (gözlem, görüşme, kaba değerlendirme, standart testler vb.) kullanıldı̆̆ına ilişkin kodlanan maddeler

\begin{tabular}{ll}
\hline Kodlanan Maddeler & f \\
\hline Zeka testi (Leiter, WISC-R), Kaba değerlendirme ve veli görüşme formu kullanılıyor & 6 \\
(Ö1, Ö3, Ö4, Ö5, Ö6, Ö7). & \\
Kaba değerlendirme formu ve görüşme formu kullanilıyor (Ö2, Ö8). & 2 \\
\hline
\end{tabular}

ÖÖG olan çocukların tanılanmasında rehberlik araştırma merkezinde kullanılan ölçme ve değerlendirme araçları ile ilgili iki farklı madde kodlanmıştır. Bu kategoride en fazla kodlanan madde (f:6) zeka testi (Leiter, WISC-R), kaba değerlendirme ve veli görüşme formu kullanılıyor iken diğer bir kodlanan madde, kaba değerlendirme formu ve görüşme formu kullaniliyor (f:2) maddesidir.

Öğretmenlerin kendi ifadelerinden bazı kesitler aşağıda yer almaktadır;

“Görüşme ve kaba değerlendirme çalışmalarında ÖÖG şüphesi oluştuğunda bunu çocuğun yaşına göre Leiter ve Wisc-r testleri ile teyit ederiz."(Ö1).

"Rehberlik araştırma merkezinde ÖÖG olan çocukları tanılamada kaba değerlendirme ve görüşme formu kullanılmaktadır."(Ö8).

Rehberlik araştırma merkezinde görev yapan özel eğitim öğretmenlerinin ÖÖG olan çocukların tanılanması sürecinde kendilerini yeterli bulma düzeylerine ilişkin üç farklı madde kodlanmıştır. Bu kategoride en fazla kodlanan madde (f:4) kendimi yetersiz buluyorum iken daha sonra sırasıyla, aldığım lisans eğitimini yeterli bulmuyorum (f:2), eğitsel değerlendirme konusunda bilgi eksikliğim olduğunu düşünüyorum (f:2) maddeleri takip etmektedir.

Tablo 10. Rehberlik araştırma merkezinde görev yapan özel eğitim öğretmenlerinin ÖÖG tanılanma sürecinde kendilerini yeterli bulma düzeylerine yönelik kodlanan maddeler

\begin{tabular}{lr}
\hline Kodlanan Maddeler & f \\
\hline Kendimi yetersiz buluyorum (Ö3,Ö5,Ö6,Ö7). & 4 \\
Aldı̆̆ım lisans eğitimini yeterli bulmuyorum (Ö4, Ö1). & 2 \\
Eğitsel değerlendirme konusunda bilgi eksikliğim olduğunu düşünüyorum (Ö8, Ö2). & 2 \\
\hline
\end{tabular}

Öğretmenlerin kendi ifadelerinden bazı kesitler aşağıda yer almaktadır; 
"Üniversiteden ilk mezun olup göreve başladığımda kendimi bu konuda çok yetersiz hissediyordum ancak rehberlik araştırma merkezinde çalışmaya başladıktan sonra kendimi geliştirdiğimi düşünüyorum. Ancak hala çok yeterli görmüyorum kendimi."(Ö4).

“Öğrenme güçlüğünün tanısı konusunda öğretmenin bakış açısı ve bilgisinin doğrudan ve dolaylı olarak etkilediğini düşünüyorum. Özel öğrenme güçlüklerinin eğitsel değerlendirilmesine yönelik hem bilgi eksiğimin hem de değerlendirmeyi zorlaştıracak kavram-olgu yanılgılarımın olduğunu düşünüyorum."(Ö6).

\section{Yönlendirme}

Tablo 11. ÖÖG tanısı almış çocukların uygun eğitim programına yönlendirilmesi sürecine yönelik izlenimlere ilişkin kodlanan maddeler

\begin{tabular}{lc}
\hline Kodlanan Maddeler & f \\
\hline ÖÖG ile ilgili yönlendirme sürecinde kaynaştırma ve veli bilgilendirmesinden başka & 3 \\
seçeneğimiz olmadığını düşünüyorum (Ö4, Ö8, Ö7). & \\
$\begin{array}{l}\text { Sınıf öğretmenlerinin sınıfına kaynaştırma öğrencisi alma ve BEP hazırlama ko- } \\
\text { nusunda isteksiz olduklarını düşünüyorum (Ö1, Ö2). }\end{array}$ & 2 \\
$\begin{array}{l}\text { Aile desteğinin alınması gerektiğini düşünüyorum (Ö6). } \\
\text { Yönlendirme sürecinde etiket kaygısından kaynaklı veli direnişi ile karşılaşıldı̆̆ını } \\
\text { düşünüyorum (Ö5). }\end{array}$ & 1 \\
$\begin{array}{l}\text { Okul idarelerinin destek eğitim odası açma konusunda isteksiz olduklarını } \\
\text { düşünüyorum (Ö3). }\end{array}$ & 1 \\
\hline
\end{tabular}

ÖÖG tanısı almış çocukların uygun eğitim programına yönlendirilmesi sürecine yönelik beş farklı madde kodlanmıştır. Bu kategoride en fazla kodlanan madde (f:3) ÖÖG ile ilgili yönlendirme sürecinde kaynaştırma ve veli bilgilendirmesinden başka seçeneğimiz olmadığını düşünüyorum iken daha sonra sırasıyla, sınıf öğretmenlerinin sınıfına kaynaştırma öğrencisi alma ve BEP hazırlama konusunda isteksiz olduklarını düşünüyorum (f:2), aile desteğinin alınması gerektiğini düşünüyorum (f:1), yönlendirme sürecinde etiket kaygısından kaynaklı veli direnişi ile karşılaşıldığını düşünüyorum (f:1), okul idarelerinin destek eğitim odası açma konusunda isteksiz olduklarını düşünüyorum (f:1) maddeleri takip etmektedir.

Öğretmenlerin kendi ifadelerinden bazı kesitler aşağıda yer almaktadır; 
"Sinı öğretmenleri ve okul idaresinin kaynaştırma öğrencisi ile ilgili bireyselleştirilmiş eğitim planı ve destek eğitim odası işlemlerinin külfetinden kaçma amaçl direnişleri bizi oldukça zorluyor"(Ö3).

"ÖÖG öğrencilerinin yönlendirilmesinde zaten çok bir tercihimiz olmamaktadır. Öğrenciye kaynaştırma yazılır ve veliye kurumda gerekli bilgilendirmeler yapılır. Ama yönlendirmenin yalnızca bunlarla sınırlı olmaması öğrenciler için daha uygun olurdu"(Ö4).

"Süreçte en çok karşılaştığımız öğrenci velisinin etiket kaygısından kaynaklanan direnişidir"(Ö5)

"Veliye çocuğun yasal haklarl, özel eğitim hizmetleri yönetmeliği ve diğer ilgili mevzuatlar hakkında gerekli bilgilendirmeyi rehberlik araştırma merkezine başvurduğu andan değerlendirme anına kadar yapıyoruz"(Ö6).

Tablo 12. ÖÖG olan çocukların uygun eğitim programına yönlendirilmesinin ardından izleme sürecinde yapılanlara ilişkin kodlanan maddeler

\begin{tabular}{ll}
\hline Kodlanan Maddeler & f \\
\hline $\begin{array}{l}\text { Destek eğitim sonunda yapılan değerlendirmelerin verimli olduğunu } \\
\text { düşünüyorum (Ö7,Ö2,Ö5,Ö6). }\end{array}$ & 4 \\
$\begin{array}{l}\text { Kademe geçişlerinde yapılan değerlendirmelerin verimsiz olduğunu } \\
\text { düşünüyorum (Ö7, Ö6). }\end{array}$ & 2 \\
$\begin{array}{l}\text { Okulda eğitsel değerlendirme formu aracılıyla yapıllan değerlendirmeleri yetersiz } \\
\text { buluyorum (Ö8, Ö4). }\end{array}$ & 2 \\
$\begin{array}{l}\text { Rehberlik araştırma merkezlerindeki yoğun iş temposu ve personel yetersizliği } \\
\text { nedeniyle sağlıklı bir değerlendirme yapılamadığını düşünüyorum (Ö1,Ö3). }\end{array}$ & 2 \\
$\begin{array}{l}\text { İzleme ve değerlendirme formları yetersiz (kaba değerlendirme) olduğu için } \\
\text { yapilan değerlendirmeleri yetersiz buluyorum (Ö8). }\end{array}$ & 1 \\
\hline
\end{tabular}

ÖÖG olan çocukların uygun eğitim programına yönlendirilmesinin ardından izleme sürecinde yapılanlara ilişkin beş madde kodlanmıştır. Bu kategoride en fazla kodlanan madde (f:4) Destek eğitim sonunda yapılan değerlendirmelerin verimli olduğunu düşünüyorum iken daha sonra sırasıyla, kademe geçişlerinde yapılan değerlendirmelerin verimsiz olduğunu düşünüyorum (f:2), okulda eğitsel değerlendirme formu aracilıyla yapılan değerlendirmeleri yetersiz buluyorum (f:2), rehberlik araştırma merkezlerindeki yoğun iş temposu ve personel yetersizliği nedeniyle sağlıklı bir değerlendirme yapılamadığını düşünüyorum (f:2), İzleme ve değerlendirme formları yetersiz (kaba değerlendirme) olduğu 
için yapılan değerlendirmeleri yetersiz buluyorum (f:1) maddeleri takip etmektedir.

Öğretmenlerin kendi ifadelerinden bazı kesitler aşağıda yer almaktadır;

"Rehberlik araştırma merkezlerinde yoğun iş ve personel yetersizliği yüzünden İzleme sürecinde çok yeterli olduğumuzu söyleyemeyiz."(Ö1).

"Rehberlik araştırma merkezi müdürlüğ̈̈ olarak görevlendirilen uzmanlar tarafindan bizzat kaynaştırma/bütünleştirme ortamlarında bir ders saati boyunca gözlenmesidir. Bu izleme türü ilk bakışta yönlendirme kararının etkililĭgini değerlendirmede oldukça verimli gibi gözükmektedir fakat uygulama sırasında kullanılan formlar ve uygulanma biçimi açısından oldukça verimsizdir. Çünkü bu izleme formunda da her yetersizlik türü için kullanılan ayn form kullanıldiğı için ÖÖG'ye yönelik özel bir veri sağlamamaktadır."(Ö3).

\section{Tartışma ve Sonuç}

Türkiye'deki tanılama süreci genel olarak farkına varma süreci ile başlayarak sırasıyla rehberlik araştırma merkezi sürecinde bir önceki aşamaya göre daha kapsamlı bir değerlendirme süreci sonrası gerek görüldügünde çocuğun risk grubunda olduğu düşünülerek tıbbı değerlendirme yapılmak üzere uygun bir sağlik kurumuna yönlendirilmesiyle devam eder. Hastane sürecinde yapılan değerlendirmeler sonucunda tıbbi olarak tanılanan uygun hizmetlerden faydalanmak üzere tekrar RAM'a gelir. Tanıya dayalı bir hizmet alımı durumu söz konusu olduğu için bu sürecin bu şekilde işlediği ifade edilebilir (MEB, 2020). Bu süreç araştırmacı tarafından farkına varma tanılama ve yönlendirme olarak ele alınmıştır. Araştırma sonuçlarına bakıldığında, ÖÖG olan çocukların ele alınan bu süreçlerin her bir basamağında çeşitli sorunlarla karşılaştığ1 görülmektedir.

Farkına varma sürecinde, ÖÖG şüphesiyle rehberlik araştırma merkezlerine yönlendirilen çoğu öğrencinin fark edildikten sonra hiçbir müdahale yapılmaksızın rehberlik araştırma merkezine yönlendirildiği görülmektedir. Az sayıda öğrenci için yapılan müdahalelerin ise genel önlemlerden öteye gitmediği ya da yetersiz müdahaleler olduğu görülmektedir. Oysa değerlendirme sürecinin işleyişi gereği özel ger- 
eksinim şüphesi bulunan çocuğun ayrıntılı değerlendirmeye gönderilmeden önce akademik, sosyal ya da davranışsal sorunların giderilmesi adına sınıf öğretmeni tarafından bu çocuklara yönelik bir takım öğretimsel uyarlamalara yer verilmesi gerekmektedir (Turnbull vd., 2013). Çünkü gönderme öncesi sürecin temel mantığı ayrıntılı değerlendirmeye ihtiyacı olmayan bireyleri tespit ederek bu bireylerin ayrıntılı değerlendirmeye tabi olmamalarını ve gereksiz yere etkilenmemelerini sağlamaktır (Kirk vd., 2006). Öte yandan araştırmada ulaşılan bu bulgu ÖÖG yetersizlik türünün doğasına bakıldığında birçok öğrencinin aslında ÖÖG olmamasına rağmen RAM'a yönlendirildiğini göstermektedir. Çünkü Amerikan Psikiyatri Birliği (2014) tarafından en son yapılan tanıma göre ÖÖG belirtileri gerekli girişimlerde bulunulmasına rağmen, altı ay devam eden kelimeleri yanlış ya da yavaş okuma, okuduğunu anlamada güçlük, harf harf söyleme ya da yazmada güçlük, yazılı anlatımda güçlük, sayı algısı ve hesaplamada güçlük ve akıl yürütmede güçlük olarak sıralanmıştır. Herhangi bir müdahalede bulunmadan çocukların RAM'a yönlendirilmesi doğru bir yaklaşım değildir. Buna parallel olarak yapılan çalışmalar gönderme öncesi süreçte yapılan müdahalenin yoğun ve sistematik olması çocukların yaşadıkların güçlüklerin aşılması ve genel eğitim sınıfında öğrenimlerine devam etmelerinde etkili olduğunu göstermektedir (Kirk vd., 2006; Strickland ve Turnbull, 1990). Ayrıca katılımciların öğretmenlerin gönderme öncesi yapılması gereken müdahaleler konusundaki bilgi düzeylerinin yetersiz olduğunu ifade etmeleride bu durumu destekler niteliktedir. Gönderme öncesi süreçte öğretmenlerin bilgi yetersizliklerinin olduğunu kanıtlayanda pek çok çalışma bulunmaktadır (Risk altındaki çocukları yönlendirme sürecinde öğretmenler tarafından doldurulan formların, prosedürü yerine getirmek için genel bilgilerle özensiz bir şekilde doldurulduğu, değerlendirmelerin objektif yapılmadığı ve formların ÖÖG'nin karakteristik özelliklerini desteklemediği için yetersiz olduğu ifade edilmiştir. Özak, Vural ve Avcıoğlu'nun (2008) rehberlik araştırma merkezi müdürlerinin gönderme tanılama yerleştirme izleme ve değerlendirmeye ilişkin görüş ve önerilerini belirlemeye yönelik yaptıkları çalışmada öğrenci tanıma dosyalarının okullardaki uzmanlar tarafından uygun şekilde doldurulmadığı sonucuna ulaşılmıştır. Yılmaz (2016) rehberlik ve araştırma merkezlerinde tanı, değerlendirme ve izleme 
süreçlerinin incelenmesi amacıyla yaptığı çalışmada değerlendirme formlarının yetersiz olduğu sonucuna ulaşmıştır. Ulaşılan bu sonuçlar mevcut çalışmayı destekler nitelikte olduğu söylenebilir.

Farkına varma sürecinde elde edilen diğer sonuçlara göre okul rehberlik servisleri tarafından herhangi bir değerlendirme yapılmadan sadece gönderme öncesi süreçte neler yapıldığına yönelik açılamalarda bunulduğu ifade edilmiştir. Bu sonuç farkına varma sürecinde bilgi düzeyinde yetersizlik olan grubun yalnızca sınıf/branş öğretmenlerinin değil psikolojik danışmanlarında bu konudaki bilgi düzeylerinin yetersiz olduğunu göstermektedir. Rehberlik araştırma merkezine yönlendirilen çocukların genellikle 6-12 yaş aralığında olduğu ifade edilmiştir. Pierangelo ve Giuliani (2006) ve Waber (2010) ÖÖG olan çocukların çoğunlukla ilkokula başladıkları dönemde fark edilmeye başladığını ifade etmişlerdir. Bu açıdan bulgular alanyazını destekler niteliktedir. Ayrıca bu yaş aralığı ÖÖG'nin erken dönemde fark edilemediği anlamına gelmektedir. Bu durumun nedeninin ise yine sınıf/branş öğretmenlerinin ÖÖG ile ilgili bilgi düzeylerinin yetersiz olduğundan kaynaklandığ söylenebilir. Benzer şekilde Yangın ve arkadaşları (2016) sınıf öğretmenlerinin ÖÖG konusundaki bilgi düzeyi eksikliği, yanlış kavram bilgisi ve ayrıca ÖÖG olan öğrencilerin eğitimlerine yönelik eksiklikler çektiklerini belirtmiştir.

Tanılama sürecinde, özel eğitim öğretmenleri rehberlik araştırma merkezinde yürütülen eğitsel tanılama sürecinin verimsiz olduğunu ifade etmişlerdir. Buna ek olarak öğretmenler, rehberlik araştırma merkezinde yapılan eğitsel tanılama sürecinin hastanede tıbbi tanılamaya yönelik yapılan eğitsel tanılama sürecinden daha nitelikli olduğunu da belirtmişlerdir. ÖÖG olan öğrencilerin tanılanmasında kullanılan ölçme ve değerlendirme araçları ile ilgili sonuçlar incelendiğinde, kullanılan araçların ağırlıklı olarak WISC-R ve Leiter zeka testleri olduğu bunun yanında kullanılan diğer yöntemlerin görüşme ve kaba değerlendirme olduğu gözlenmiştir. Eğitsel değerlendirme sürecinin doğasına bakıldığında kullanılan tekniklerin çeşitlilik bakımından yetersiz olduğu söylenebilir (Avcıoğlu, 2014). Benzer şekilde Yanık (2016) RAM sürecini ele aldığı bir çalışmasında RAM'lar da kullanılan değerlendirme araçlarının yetersiz olduğu sonucuna ulaşmıştır. Bu bulgunun araştırma bulgularıyla örtüştüğü görülmektedir. Tanılama sürecindeki bulgularda, 
RAM'da yürütülen tanılama sürecinde görev yapan özel eğitim öğretmenlerinin çoğunlukla kendilerini yetersiz buldukları dikkat çekmektedir. Bunun yanında ÖÖG olan çocukların tanılanmasında aldıkları lisans eğitimlerini yetersiz buldukların ifade edenler olduğu gibi eğitsel değerlendirme konusunda bilgi eksikliklerinin olduğunu ifade edenlerde olmuştur. Benzer şekilde Çakmak (2019) ÖÖG konusunda bilgi eksikliği ve RAM personelinin eğitim gereksinimine vurgu yapmıştır.

Yönlendirme sürecinde, özel eğitim öğretmenleri ÖÖG tanısı alan öğrencilerin yönlendirilmesinde kaynaştırma/bütünleştirme uygulamasından başka bir seçenek olmadığını belirtmişlerdir. Bazı özel eğitim öğretmenleri sınıf öğretmenlerinin sınıfına kaynaştırma öğrencisi alma ve bireyselleştirilmiş eğitim planı hazırlama konusunda isteksiz olduklarını belirtmiştir. Güven ve Balat (2006) kaynaştırma uygulamalarına ilişkin rehber öğretmenler ve rehberlik araştırma merkezi çalışanlarının görüşlerini belirlemeye yönelik yaptıkları çalışmada rehber öğretmenlerin ve rehberlik araştırma merkezi çalışanlarının kaynaştırma uygulamalarının yetersiz olduğunu düşündüklerini belirlemişlerdir. Araştırma sonuçları karşılaştırıldığında bu yetersizliğin öğretmenlerin isteksizliklerinden kaynaklandığı düşünülebilir. Bazı özel eğitim öğretmenleri okul müdürlerinin de destek eğitim odası açma konusunda isteksiz olduklarını belirtmiştir. Aydın Dalga (2019) tarafından yürütülen bir çalışmada okul idarelerinin destek eğitim odası uygulamasının yürütülmesinde okul idarelerinden kaynaklanan bir takım sorunların olduğunu belirtmiştir. Mevcut araştırma bu bulguyu desteklemektedir. Ayrıca bazı özel eğitim öğretenleri yönlendirme sürecinde etiket kaygısından kaynaklı veli direnişi ile karşılaştıklarını belirtmişlerdir. Tüm yetersizlik türlerinde olduğu gibi (Ardıç, 2013) ÖÖG olan çocukların ailelerinin de çocuklarının etiketlenme kaygıları olduğu görülmektedir. İzleme uygulaması ile ilgili olarak özel eğitim öğretmenleri destek eğitim sonunda yapılan değerlendirmelerin verimli olduğunu ancak kademe geçişlerinde ve okulda yapılan değerlendirmelerin verimsiz olduğunu ifade etmiştir. Ayrıca izleme ve değerlendirme formlarının yetersiz (kaba değerlendirme) kaldığını dile getirmişlerdir. Son olarak ise özel eğitim öğretmenleri tarafından, rehberlik araştırma merkezlerinde yoğun iş temposu ve personel yetersizliği nedeniyle sağlıklı değerlendirmelerin yapılamadığı belirlenmiştir. Özak ve diğerlerinin (2008) rehberlik araştırma merkezi 
müdürlerinin gönderme tanılama yerleştirme izleme ve değerlendirmeye ilişkin görüş ve önerilerini belirlemeye yönelik yaptıkları çalışmada rehberlik araştırma merkezinde görev yapan özel eğitim alan öğretmenlerinin sayısının yetersiz olduğu ortaya koyulmuştur. Bu bulgu mevcut araştırma ile tutarlılık göstermektedir.

Tüm bu sonuçlar değerlendirildiğinde, literatürde yer alan ve süreci farklı şekillerde ele alan diğer çalışmalardan (Özak vd., 2008; Aydın Dalga, 2019; Güven ve Balat, 2006; Yılmaz, 2016) elde edilen sonuçların mevcut çalışma ile paralellik gösterdiği görülmektedir.

ÖÖG tanılama süreci, ekip çalışması gerektiren çok yönlü bir süreçtir. (Öğülmüş, 2016) Rehberlik araştırma merkezlerinde yürütülen bu süreç araştırmacılar tarafından farkına varma, tanılama ve yönlendirme olarak ele alınmıştır. Üç bölüm olarak incelenen bu süreçler bir bütündür. Bu bütünün her hangi bir parçasında sorunların ortaya çıkması ÖÖG olan çocukların doğru bir şekilde tanılanmasını olumsuz etkileyecektir. Bu olumsuzluk ÖÖG olan çocuğun eğitim hayatını adım adım olumsuz olarak etkileyecek; doğru yönlendirmelerin yapılamaması ve doğru eğitim programından faydalanamamasına nihai olarak özel gereksinimlerinin yeterli miktarda giderilmemesine yol açacaktır. Elde edilen sonuçlar doğrultusunda aşağıdaki öneriler getirilmiştir.

- ÖÖG olan çocukların tanılanmasında rehberlik araştırma merkezlerinde gerçekleştirilen tanılama süreci daha verimli hale getirilmek üzere çok boyutlu bir şekilde yürütülebilir.

- Rehberlik araştırma merkezlerinde ve okullarda izleme ve değerlendirme amaçlı kullanılan araçlar gözden geçirilebilir.

- Öğretmenlerin RAM'a gönderme öncesinde çocukta ortaya çıkan durumların (akademik başarısızlık, problem davranışlar vb.) doğrudan ÖÖG'den kaynaklanıp kaynaklanmadığını belirlemeye yönelik yapabileceği müdahaleler ile ilgili hizmet içi eğitimler almaları sağlanabilir.

- Değerlendirme ve inceleme süreçlerinde rehberlik araştırma merkezlerinde görev yapan özel eğitim öğretmenleri ve okul rehber öğretmenlerine ÖÖG ile ilgili eğitsel değerlendirme süreçleri hakkında ve genel bilgi düzeylerini arttırmaya yönelik hizmet içi eğitim desteği sağlanabilir. 
- Ailelerin sürece aktif katılımlarını sağlamak üzere alternatif modeller geliştirilebilir.

- Hastane ve rehberlik araştırma merkezlerinde yapılan değerlendirmeler (eğitsel değerlendirmeler ve zeka testleri) tek kurum üzerinde birleştirilebilir.

- ÖÖG olan öğrencilerin yönlendirilmesi için kaynaştırma/bütünleştirme uygulamasının yanında bu uygulamaya alternatif olacak farklı eğitim uygulamaları geliştirilebilir.

- Rehberlik araştırma merkezlerinde ÖÖG olan öğrencilerin değerlendirilmesinde kullanılan araçların (zeka testi, standart olmayan testler) hem nicelik hem de nitelik açısından zenginleştirilebilir. 
EXTENDED ABSTRACT

\title{
Investigation of the Diagnosis Process of Individuals with Specific Learning Difficulties in Turkey from the Perspective of the Guidance Research Center
}

\author{
Kürşat Öğülmüş \\ Kırıkkale University
}

SLD is a type of inadequacy that causes some difficulties in reading, writing and mathematical skills (Melekoğlu, 2016). Although the history of the studies conducted by experts dates back a century from today, SLD is a special education field that has recently started to gain awareness in Turkey (Görgün and Melekoğlu, 2019). Considering its prevalence, individuals diagnosed with SLD in the United States (USA) constitute $42 \%$ of all individuals with special needs (Cortiella and Horowitz, 2014). This rate is only 3\% in Turkey (Melekoğlu, 2016). Assuming that the situation in the USA will be similar in Turkey, it is thought that the difference in Turkey is due to some problems in the diagnosis systems. Educational diagnosis is carried out in order to facilitate the taking of the right decisions in meeting the needs of the individual and to determine their special needs by revealing what they can do educationally (Avcioğlu, 2014). Educational diagnosis is very important in terms of making the right decisions about the educational life of the individual (Taylor, 2014). For this reason, the sooner the differences in the individual are noticed, in other words, the sooner the educational diagnosis is made, the higher the positive reflections of the individual on the educational planning will be (Lange \& Thompson, 2006). Therefore, the disruptions in the educational diagnosis process, which is so important for the education life of individuals with special needs, will adversely affect the education life of these individuals. For this reason, the aim of this research is to identify the problems that arise in the educational diagnosis process of children with SLD in Turkey, and to develop solutions for eliminating these problems. The research is a qualitative research and was designed with a phenomenology pattern. Phenomenological studies are studies that focus on phenomena that are 
aware of but do not have a detailed and in-depth understanding (Cropley, 2002). In such studies, data are obtained by interviewing individuals or groups who live and reflect the phenomenon studied (Büyüköztürk et al., 2018). Eight special education teachers were included in the research in accordance with the principle. The participants are special education teachers working in the Guidance Research Centers' (GRC) educational diagnosis unit. The data collected from the teachers within the scope of the study were collected through semi-structured interviews through the interview form developed by the researcher. The semi-structured interview form consists of two parts. In the first part, there are statements that reveal the descriptive characteristics of the participants (age, gender, professional experience, education level, etc.). In the second part, there are statements containing questions to determine the situation that arises during the identification of students with SLD. The data obtained were analyzed by content analysis. When the findings are examined, it is seen that various problems are experienced in all the steps of the diagnostic process. It is seen that children who are first noticed in the classroom environment during the recognition process are directed to GRC without any intervention after being noticed. It is seen that the interventions made for a small number of students do not go beyond general evaluation. According to the other results obtained in the recognition process, it was stated that the school guidance services only made explanations about what was done in the pre-referral process without any intervention.

During the diagnosis process, special education teachers stated that the educational diagnosis process carried out in the GRC was inefficient. When the results of the evaluation tools used in the diagnosis of students with SLD were examined, it was observed that the tools used were mainly WISC-R and Leiter intelligence tests, and the other methods used were interview and general evaluation. Considering the nature of the educational evaluation process, it can be said that the techniques used are insufficient in terms of diversity (Avcioğlu, 2014). During the orientation process, special education teachers stated that there was no other option other than inclusion/integration for the students diagnosed with SLD. Some special education teachers stated that primary school teachers are reluctant to accept these students in their classes and to prepare an individual education plan. 
The SLD diagnosis process is a multifaceted process that requires teamwork. (Öğmüş, 2016) This process, which is carried out in GRC, has been handled by researchers as recognition, diagnosis and guidance. These processes, which are examined in three parts, are a whole. The emergence of problems in any part of these will negatively affect the correct diagnosis of children with SLD. This negativity will negatively affect the education life of the child with SLD. In line with the results obtained, some of the recommendations made are in the following:

- It can be ensured that teachers receive in-service training on determining whether the situations that arise before sending students to GRC are directly caused by SLD.

- In-service training support on educational evaluation processes related to SLD can be provided to special education teachers and school counselors who work in the recognition, diagnosis and guidance processes.

- The tools used in the evaluation of students with SLD in the GRC can be enriched in terms of both quantity and quality.

- In addition to the mainstreaming/integration practice, different educational practices can be developed as an alternative to this practice in order to guide students with SLD.

\section{Kaynakça / References}

Aksoy, V. ve Şafak, P. (2020). 573 sayılı KHK'dan günümüze özel eğitimde eğitsel tanılama ve değerlendirme: Neredeyiz, nereye gitmeliyiz? Turkish Journal of Special Education Research and Practice, 2(1), 47-67. https://doi.org/10.37233/TRSPED.2020.0108.

Amerikan Psikiyatri Birliği. (2014). Ruhsal bozukluklar tanısal ve sayılmsal elkitabı, beşinci baskı (DSM-5), tanı ölçütleri başvuru elkitabı [Diagnostic and statistical manual of mental disorders]. (Çev. E. Köroğlu). Hekimler Yayın Birliği: Ankara.

Ardıç, A. (2013). Özel gereksinimli çocuk ve aile. A. Cavkaytar (Ed), Özel eğitimde aile eğitimi ve rehberliği içinde (s.19-52). Ankara: Vize Yayıncilik.

Avcıoğlu, H. (2014). Özel gereksinimi olan bireylerin değerlendirilmesi. Ankara: Vize Yayıncilı.

Avcıoğlu, H. (2012). Rehberlik ve Araştırma Merkez (RAM) müdürlerinin tanılama, yerleştirme-izleme, Bireyselleştirilmiş Eğitim Programı 
(BEP) geliştirme ve kaynaştırma uygulamasında karşılaşılan sorunlara ilişkin algıları. Kuram ve Uygulamada Eğitim Bilimleri, 12(3), 20092031.

Aydın Dalga, R. (2019). Destek eğitim odasında görev alan öğretmenlerin özel öğrenme güçlüğü olan öğrencilerle yaptıkları eğitim öğretime ilişkin görüş ve önerileri.(Yüksek lisans tezi). Marmara Üniversitesi, Eğitim Bilimleri Enstitüsü, Özel Eğitim Anabilim Dalı, İstanbul.

Büyüköztürk, Ş., Kılıç Çakmak, E., Akgün, Ö. E., Karadeniz, Ş. ve Demirel, F. (2018). Bilimsel araştırma yöntemleri. Ankara: Pegem Akademi.

Cortiella, C. and Horowitz, S. H. (2014). The state of learning disabilities: Fact, trends and emerging issues (3rd ed.). New York: National Center for Learning Disabilities.

Cropley, A. (2002). Qualitative research methods. An introduction for students of psychology and education. University of Latvia: Zinatne.

Çakıroğlu, O. (2018). Özel öğrenme güçlüğüne giriş. M. A. Melekoğlu ve U. Sak (Ed), Öğrenme güçlüğ̈̈ ve özel yetenek içinde (s.2-21). Ankara: Pegem Akademi.

Çakmak, Z. (2017). Rehberlik ve araştırma merkezi personelinin öğrenme güçlüğü olan bireylerin değerlendirilme süreçlerine ilişkin görüşleri (Yüksek lisans tezi). Anadolu Üniversitesi, Eğitim bilimleri Enstitüsü, Özel Eğitim Anabilim Dall, Eskişehir.

Görgün, B. ve Melekoğlu, M. A. (2019). Türkiye'de özel öğrenme güçlüğü alanında yapılan çalışmaların incelenmesi. Sakarya University Journal of Education, 9(1), 83-106.

Güven, Y. ve Balat, G. U. (2006). Kaynaştırma uygulamalarına ilişkin rehber öğretmenler ve rehberlik araştırma merkezi çalışanlarının görüşleri. M.Ü. Atatürk Eğitim Fakültesi Eğitim Bilimleri Dergisi, 24, 95-108.

Karasar, N. (2002). Bilimsel araştırma yöntemi. Ankara: Nobel Yayıncllık.

Karataş, Z. (2015). Sosyal bilimlerde nitel araştırma yöntemleri. Manevi Temelli Sosyal Hizmet Araştırmaları Dergisi, 1(1), 62-80.

Korkmazlar, Ü. (1992). 6-11 yaş ilkokul çocuklarında özel öğrenme bozukluğu ve tanı yöntemleri. Yayınlanmamış doktora tezi. İstanbul Üniversitesi, Sağlık Bilimleri Enstitüsü, Halk Sağlığı Anabilim Dalı, İstanbul.

Kirk, A. S., Gallagher, J.J., Anastasiow, J.N. and Coleman, R.M.(2006). Educating exceptional children. (12th ed). Boston: Houghton Mifflin. 
Lange, S. M. and Thompson, B. (2006). Early identification and interventions for children at risk for learning disabilities. International Journal of Special Education, 21(3), 108-119.

Mason, J. (1996). Qualitative researching. London: Sage Publication.

Melekoğlu, M. A. (2016). Özel öğrenme güçlügüne giriş. M. A. Melekoğlu ve O. Çakıroğlu (Ed), Özel öğrenme güçlü̆̆̈̈ olan çocuklar içinde (s.15-44). Ankara: Vize Yayıncilık.

Miller, S. (2003). Analysis of phenomenological data generated with children as research participants. Nurse Researcher, 10(4), 68-82.

Miles, M. B. and Huberman, A. M. (1994). Qualitative data analysis: An expanded sourcebook. Beverly Hills, CA: Sage.

MEB. (2018). Özel Eğitim Hizmetleri Yönetmeliği. Ankara: Milli Eğitim Bakanlığ1.

MEB. (2020). Rehberlik Araştırma Merkezi Yönergesi. Ankara: Milli Eğitim Bakanlığı.

Taylor, A. E. B. (2014). Diagnostic assessment of learning disabilities in childhood: Bridging the gap between research and practice. Springer Science \& Business Media.

Ögülmüss, K. (2016). Özel öğrenme güçlüğü olan öğrenciler için geçiş hizmetleri. M. A. Melekoğlu ve O. Çakıroğlu (Ed), Özel öğrenme güçlü̆̆̈̈ olan çocuklar içinde (s.325-337). Ankara: Vize Yayıncılık.

Özak, H., Vural, M.ve AVCIOĞLU, H. (2008). Rehberlik ve Araştırma Merkezi Müdürlerinin gönderme tanılama yerleştirme izleme ve değerlendirmeye ilişkin görüş ve önerileri. Abant İzzet Baysal Üniversitesi Eğitim Fakültesi Dergisi, 8(1), 189-206.

Pierangelo, R. and Giuliani, G. (2006). Learning disabilities: A practical approach to foundations, assessment, diagnosis and teaching. Boston: Pearson.

Strickland, B.B. and Turnbull, A.P. (1990). Developing and implementing individualized education programs. Columbus $\mathrm{OH}$ : Merrill.

Tiryakioğlu, Ö. ve Avcıoğlu, H. (2013). Rehberlik ve araştırma merkezi müdürlerinin özel eğitim bölümünün sorunlarını algılamaları. Turkish International Journal of Special Education and Guidance \& Counselling (TIJSEG), 2(1), 13-29.

Turnbull, A., Turnbull, R., Wehmeyer, M. L. and Shogren, K. A. (2013). Exeptional lives: Special education in today's schools. (7th. Ed.). Boston: Pearson. 
Waber, D. P. (2010). Rethinking learning disabilities: Understanding children who struggle in school. London: The Guilford Press.

Yangın, S., Yangın, N., Önder, V. ve Şavlığ, A. (2016). Sınıf öğretmeni adaylarının ve öğretim elemanlarının çeşitli öğrenme güçlüklerine yönelik farkındalıkları. Education Sciences, 11(4), 243-266.

Yanık, Ş. (2016). Isşitme yetersizliği olan ilkokul öğrencilerinin kaynaştırma ortamlarna yönlendirme ve yerleştirme süreçlerinin incelenmesi (Yayımlanmamış Yüksek Lisans Tezi). Anadolu Üniversitesi, Eğitim bilimleri Enstitüsü, Özel Eğitim Anabilim Dalı, Eskişehir.

Yıldırım, A. ve Şimşek, H. (2003). Sosyal bilimlerde nitel araştırma yöntemleri. Ankara: Seçkin Yayıncılık.

Yılmaz, Y. (2016). Rehberlik ve araştırma merkezlerinde tanı, değerlendirme ve izleme süreçlerinin incelenmesi: İşitme kayıplı çocuklar örneği. Yayınlanmamış Yüksek Lisans Tezi. Anadolu Üniversitesi, Eğitim Bilimleri Enstitüsü, Özel Eğitim Anabilim Dalı, Eskişehir.

Yurtsever, Ş. (2013). Eğitsel tanılama ve değerlendirme sürecinde görev alan rehberlik ve araştırma merkezi personelinin karşılaştı̆̆̆ sorunların belirlenmesi (Yayımlanmamış Yüksek Lisans Tezi). Marmara Üniversitesi, Eğitim Bilimleri Enstitü, Özel Eğitim Anabilim Dalı, İstanbul.

\section{Kaynakça Bilgisi / Citation Information}

Öğülmüş, K. (2021). Türkiye'de özel öğrenme güçlüğü olan bireylerin tanılama sürecinin Rehberlik Araştırma Merkezi perspektifinden incelenmesi. OPUS-Uluslararası Toplum Araştırmaları Dergisi, 18(Eğitim Bilimleri Özel Sayısı), 4176-4204. DOI: 10.26466/opus. 948202. 